\title{
ELISEO DIEGO: DEFINICION DE UN POETA
}

\author{
POR \\ ENRIQUE SAINZ \\ Academia de Ciencias de Cuba, \\ Instituto de Literatura y Linguística
}

Eliseo Diego (1920) se inició muy joven en las letras. Fina García Marruz lo recuerda "por el otoño de 1941» abriendo «su gastado cuaderno de tapas negras para leernos sus primeras prosas» ', publicadas un año más tarde con el título de un verso de Quevedo: En las oscuras manos del olvido. En 1946 aparecería Divertimentos, otro conjunto de narraciones - a ellos hay que añadir un tercero y último libro de prosa de ficción: Noticias de la quimera (1975), de similares virtudes- que confirmaba la madurez alcanzada por su autor desde muy temprano, en una adolescencia escrutadora y ávida, sedienta de perfección y al mismo tiempo asombrada por lo que podríamos denominar, con frase de un escritor admirado por nuestro poeta, las enormes minucias de la cotidianeidad de una infancia intensamente vivida. Una simple lectura de placer nos revela que en esos dos libros hay una voluntad de estilo que ha ido conformándose después de numerosos y detenidos diálogos con los grandes maestros del idioma. Estos inicios nos entregan un estilo alcanzado gracias a un trabajo constante de reelaboración, como observa la propia García Marruz: «el manuscrito dejaba ver en sus muchas palabras tachadas o superpuestas la huella de la angustiosa búsqueda del vocablo exacto, preciso» ${ }^{2}$. Pero no se trata sólo de una lúcida asimilación de carácter formal y de un primer momento en la trayectoria de un poeta en el caso de estos dos cuadernos de prosa: en ellos está esa peculiar manera de percibir y sentir el entorno, un importantísimo elemento integrador de su poesía.

Eliseo Diego, miembro del Grupo Orígenes prácticamente desde sus

1 Fina García Marruz, «Ese breve domingo de la forma» [1970], en su Hablar de la poesía [Ensayos] (La Habana: Editorial Letras Cubanas, 1986), p. 396.

${ }^{2}$ Idem. 
primeros pasos adultos en la literatura, nutre su cosmovisión, en su alcance mayor, de sus postulados, expuestos de manera magistral una y otra vez por Cintio Vitier ${ }^{3}$. De ese cuerpo de ideas nos interesa destacar dos: la que considera que la poesía (y en general la cultura) es la posibilidad de rescate «frente a la traición y a la chapucería» ${ }^{4}$ de los gobiernos de turno y la que plantea la necesidad de recomenzar con la mirada vuelta hacia la tradición y a partir de un concepto nuevo del fenómeno poético, pues en ambas encontramos la raíz de sustanciales diferencias de Eliseo Diego con su contexto literario. En oposición a la poesía social, que tiene como temas el acontecer histórico y los conflictos del individuo o de un grupo en sus estrechas relaciones con la sociedad, la poesía de Diego se vuelve hacia el entorno inmediato, el de los objetos, los sitios, las costumbres, la vida familiar, signos de una convivencia que va conformando un pasado al mismo tiempo que da cuerpo a la obra de resistencia frente a la Nada existencial y el vacío de la frustración política. En la Calzada de Jesús del Monte (1949) es un libro en el que su autor se propuso «no sólo grabar los secretos de la infancia y de la Isla sobre el fondo entrañable de "la Calzada más bien enorme de Jesús del Monte", sino también dibujar para

\footnotetext{
${ }^{3}$ Véanse Diez poetas cubanos (1937-1947). Antología y notas de Cintio Vitier (La Habana: Orígenes, 1948); Cincuenta años de poesía cubana (1902-1952). Ordenación, antología y notas por Cintio Vitier (La Habana: Dirección de Cultura del Ministerio de Educación, 1952); Cintio Vitier, Lo cubano en la poesía (La Habana: Universidad Central de Las Villas, 1958; 2. ${ }^{a}$ ed. La Habana, Instituto del Libro, 1970); Cintio Vitier, "Introducción a la obra de José Lezama Lima», en José Lezama Lima, Obras completas. Tomo I. Novela/Poesía completa. Introducción de Cintio Vitier (México: Aguilar, 1975), pp. XI-LXIV, y Cintio Vitier, Ese sol del mundo moral. Para una historia de la eticidad cubana (México, D.F.: Siglo XXI, 1975). Véase, además, el libro de Roberto Fernández Retamar, La poesía contemporánea en Cuba (1927-1953) (La Habana: Orígenes, 1954). Para llegar a conocer a fondo los planteamientos del Grupo Orígenes son imprescindibles los textos de su figura mayor, Lezama Lima, consignados en el Instituto de Literatura y Lingüística de la Academia de Ciencias de Cuba. Diccionario de la literatura cubana. Tomo I. Prólogo de José Antonio Portuondo (La Habana: Editorial Letras Cubanas, 1980), así como los cuarenta ejemplares de la revista Orígenes (1944-1956). Para el conocimiento de la obra de Eliseo Diego son de extraordinaria importancia los trabajos de Vitier (véase la nota 3), las páginas que le dedica Roberto Fernández Retamar en su libro ya mencionado y el formidable ensayo de interpretación de Alain Sicard, «En un roce inocente de la luz (para una poética de Eliseo Diego)», en Casa de las Américas (La Habana, año XXV, núm. 149, marzo-abril 1985), pp. 142-146, así como las reflexiones del propio poeta en torno a su obra, expuestas en dos textos: «Esta tarde nos hemos reunido», conferencia pronunciada en el Lyceum y editada en Nueva Revista Cubana (La Habana, año I, núm. 1, abril-mayo-junio, 1959), y «A través de mi espejo», conferencia leída en la Biblioteca Nacional «José Martí» y publicada en Unión (La Habana, núm. 4, año IX, dic. 1970), pp. 5-20, ambas recogidas en Eliseo Diego. Prosas escogidas. Prólogo de Aramís Quintero (La Habana: Editorial Letras Cubanas, 1983), pp. 281-308 y 466-485, respectivamente.

${ }^{4}$ Cintio Vitier, «Introducción a la obra de José Lezama Lima», op. cit., p. XVI.
} 
todos el árbol de la vida histórica, el árbol genealógico de nuestra sangre y nuestro espíritu», ha dicho Cintio Vitier ${ }^{5}$.

La búsqueda de la identidad en el acto de comunión del poeta con sus más cercanas vivencias crea todo un estilo y un modo de decir que no teníamos en la poesía cubana hasta ese momento. Logros perdurables habían alcanzado los mejores poetas cubanos que por los años cuarenta estaban en pleno quehacer ${ }^{6}$. Con su poemario de 1949 Eliseo Diego trae a la poesía la apertura hacia un diálogo nuevo, un acercamiento de múltiples significados al ámbito cotidiano. De manera implícita hallamos en estos versos la conciencia de que es necesario recrear nuestra tradición a partir de otra experiencia artística, radicalmente distinta de las que conformaban el panorama de nuestra literatura en esos años. Si nos detenemos en el análisis de cualquiera de los poemas de En la Calzada de Jesús del Monte y lo comparamos con textos de la tendencia purista o del mejor intimismo, o incluso con los más representativos de Lezama, de Vitier o de García Marruz - los más destacados integrantes, con el propio Diego, del Grupo Orígenes-, nos percataremos de que estamos ante una voz inconfundible y de extraordinaria riqueza de tonos y matices, ante una obra de penetrante percepción. Un ejemplo para comprender la significación de este libro podría ser «El segundo discurso: aquí un momento», toda una poética en la que se conjugan los elementos de una obra de asombrosa coherencia. La infancia, la luz y la penumbra, la conformación del individuo desde su pasado, la función creadora de la memoria afectiva, las estancias de la convivencia y del reencuentro de sí mismo, la fusión de la realidad y el sueño y el diálogo con los objetos hacen de este poema un paradigma de una concepción de la poesía que no tenía precedentes en la historia del género en Cuba. Para ilustrar nuestras palabras tomemos estos fragmentos con su enorme carga de símbolos, asociaciones e interrelaciones de planos de la realidad:

${ }^{5}$ Cintio Vitier, «En la Calzada de Jesús del Monte» [1949], en su Crítica sucesiva (La Habana: UNEAC, 1971), pp. 217-229. La cita es de la página 228.

${ }^{6}$ Nos referimos a los poetas que comienzan a escribir o alcanzan su plenitud después de 1923 e integran las distintas tendencias que surgen de la vanguardia o que, como en el caso del intimismo, contaban ya con una larga trayectoria. Tenemos, pues, que en la década del cuarenta encontramos en la poesía cubana las siguientes tendencias: social (Regino Pedroso, Manuel-Navarro Luna, Nicolás Guillén), negrista (Ramón Guirao, Emilio Ballagas, Guillén), poesía pura (Mariano Brull, Ballagas, Eugenio Florit, estos últimos en sus primeros libros), poesía intimista (Dulce María Loynaz, Mirta Aguirre, Ballagas, Florit, ambos a partir de la segunda mitad de la década del treinta) y poesía origenista. Como representativos de cada tendencia hemos dado los nombres de aquellos que consideramos más importantes. Para las definiciones, los límites cronológicos, los autores dentro de cada tendencia y toda una serie de pormenores de mayor o menor significación de la vanguardia y del posterior desarrollo de nuestra lírica hasta 1953, véase el libro de Roberto Fernández Retamar citado en la nota 3. 
Aquí en el patio, junto

a las columnas romanas, impasibles

en su agobiada pesadumbre, altas,

y mientras hiere mi garganta

la transparencia de la noche,

tan profunda, tan limpia

que saciara la sed de mi tiniebla,

mientras recuento los brocados

y otras riquezas oscuras de mi tedio

con la mano sagaz, la mano ciega,

y confundo las palmas

con los desgarradores sucedidos

en la tarde del Viernes ${ }^{\text {, }}$

Y ahora es el tiempo de levantarme y de trazar mi amplio gesto diciendo:

luego de la primera muerte, señores, las imágenes,

invéntense los jueves,

los unicornios, los ciervos y los asnos

y los frutos de la demencia ${ }^{8}$.

Desde el punto de vista estilístico, el libro expresa la plenitud de su autor, totalmente hecho ya, en el sentido artístico, desde el cuaderno de 1942. Había asimilado los hallazgos formales de la vanguardia para entregarnos una nueva experiencia creadora que la poesía cubana no había logrado aún, una riquísima relación con la realidad más allá de todo exteriorismo superficial y de la esbeltez y anhelo de perfección de la poesía pura. Observemos, además, que en oposición a la tendencia purista, las búsquedas de Eliseo Diego parten del carácter inmanente de los objetos y de la naturaleza, sin pretensiones que quieran llegar a un conocimiento suprasensible. Desde En las oscuras manos del olvido sentimos la presencia de las cosas, su enorme gravedad y los duros y resistentes contornos de su ser, deslumbrado el poeta precisamente por esa capacidad de resistencia frente a la voracidad de la Nada, uno de los temas constantes a lo largo de toda su obra hasta hoy.

En ese primer poemario y en los sucesivos (Por los extraños pueblos, 1958; El oscuro esplendor, 1966; Muestrario del mundo o Libro de las maravillas de Boloña, 1968; Versiones, 1970; Los días de tu vida, 1977; A través de mi espejo, 1982, e Inventario de asombros, 1983) ${ }^{9}$ tiene la

${ }^{7}$ En la Calzada de Jesús del Monte (La Habana: Ucar García, 1947 [i.e., 1949]), páginas $20-21$.

${ }^{8}$ Idem.

${ }^{9}$ Menos los dos últimos títulos y Veintiséis poemas recientes (México: Ediciones del Equilibrista, S. A. de C. V., 1986), que incluye algunos poemas que no habían aparecido 
poesía cubana, como en ningún otro corpus, un canto a la plenitud y el esplendor de los sitios, las estancias y el paisaje, el afuera y el adentro degustados por igual en sus colores, sus texturas, su solidez. Los puristas se encaminan en una dirección opuesta, en el caso de Brull hacia el encuentro de una verdad arquetípica más allá de la realidad sensorial, quizá el único poeta entre nosotros poderosamente tocado por el ansia de perfección que canta «A la rosa desconocida», imposible ontológico que condujo a su autor a un progresivo nihilismo, como el que asoma en «À toi même», texto confesional que viene a darnos el testimonio de una profunda crisis, decididamente insalvable ya para el individuo. Incluso no puede identificarse la necesidad de hallar un estado anterior a la experiencia de los sentidos (de mayor envergadura en Ballagas que en Brull y que en Florit) con las preocupaciones de Diego por revivir el pasado - recordemos la función creadora de la memoria afectiva desde las narraciones de 1942-, pues en su poética hay una vivencia que podríamos calificar de suficiente y autogeneradora, en tanto que en Ballagas se trata precisamente de su opuesto: el anhelo de lo inapresable, la conciencia de un vacío interior que el poeta no podrá colmar, como se aprecia en el clamor de «Sentidos», de Júbilo y fuga (1931).

Muy estrechamente relacionado con este inmanentismo de la poesía de Eliseo Diego está el rasgo que la diferencia de la lírica intimista y del criollismo. El poeta se ha referido a su condición de espectador («para mí, [la poesía] es el acto de atender en toda su pureza» ${ }^{10}$ ), de testigo ( No es por azar que nacemos en un sitio y no en otro, sino para dar testimonio» ${ }^{11}$ ), de simple relator de los sucesos que conforman el centro de su vida interior («Escribo todo esto con la melancolía de quien redacta un documento» ${ }^{12}$ ). Su diálogo con el mundo circundante no está ceñido a los estrechos límites de la resonancia afectiva, lo cual le permite penetrar más hondo en sus indagaciones y afanes para llegar a un desentrañamiento poético de mayor perdurabilidad, más pleno. El libro de 1949 ha dejado atrás, a su vez, el exteriorismo superficial del criollismo ingenuo, al que escapan las riquezas ocultas que de modo incomparable nos revela Eliseo Diego. Esta actitud indagadora, una poética que se desentiende de los conflictos y las angustias del hombre en el sentido que dieron los románticos a esas problemáticas, hace de este creador una antítesis asimismo de los poetas efusivos, de los poetas tocados por el entusiasmo. Es el suyo un discurso sosegado, despa-

en sus libros, toda su obra fue recogida en Poesía. Prólogo de Enrique Sainz (La Habana: Editorial Letras Cubanas, 1983).

10 «Dedicatoria», en su Por los extraños pueblos (La Habana: Ucar García, 1958), p. [6].

11 Idem.

12 «La quinta», en su En la Calzada de Jesús del Monte, p. 65. 
cioso, lento, fruitivo, sin exaltaciones temperamentales, dado esencialmente a la contemplación y al disfrute, reposado, como de quien ha estado siempre inmerso en una tradición de la más rica sabiduría. Sus libros nos entregan una profunda experiencia de participación, como si hablásemos con alguien que ha convivido largamente con las cosas y la llegado, gracias a su penetrante mirada y a una reflexión que nada tiene que ver, como voluntad expresiva, con una determinada corriente filosófica, a una conclusión medular: la multiplicidad y riqueza del mundo cotidiano. Veamos, a modo de ilustración, este poema:

\section{LA MESA}

La mesa, la inocente criatura reposada y cándida, extiende su silencio entre la luz, en oro duerme.

Allí la hora es la madera, la nocturna; es el color gastado, la superficie de la mesa cándida.

Sopla el frío en el árbol, cambia la luz, el tiempo, y otra criatura tiembla con callado pavor entre la sombra ${ }^{13}$.

Ningún otro poeta en la historia de la literatura cubana ha logrado un acercamiento tan fecundo a su universo circundante. La obra de los restantes miembros del Grupo Orígenes se diferencia además, de la de Diego, entre otros elementos, por este que acabamos de señalar. En Lezama y en Vitier, por ejemplo, se aprecia una expresión de mayor densidad, consustancial con sus apetencias de apoderamiento de la realidad como un ente uno y diverso, mucho más ostensible en el autor de La fijeza que en Vitier. En ambos - y en Fina García Marruz, aunque en menor medida- hay un impulso primigenio de extraordinaria fuerza que tenemos que identificar con preocupaciones diferentes a las que observamos en el poeta que hoy nos ocupa. En Diego hay una tradición asentada en el vivir de todos los días, fundada en lo que podríamos denominar el ente inmediato. Esa es una distinción que nos parece sustancial a la hora de esclarecer la poética de estos creadores. Toda la obra de Diego insiste, de un modo reiterado y muy peculiarmente suyo, en la antítesis ser-no ser, de la que surgen

\footnotetext{
${ }_{13}$ Por los extraños pueblos, p. 63.
} 
todos sus rasgos caracterizadores. La manera de abordar ese conflicto distingue sus libros dentro del riquísimo panorama de la lírica cubana desde hace cuatro décadas. Del deslumbramiento inicial de En la Calzada de Jesús del Monte pasamos al tono meditativo de los textos de Muestrario del mundo [...] y en general de sus restantes libros hasta Inventario de asombros, un acendramiento gradual que no significa transformaciones en la cosmovisión, pues en los dos primeros poemarios hallamos también páginas de honda meditación y en los sucesivos un asombro idéntico al de los inicios, dualidad inseparable. Compárense, por ejemplo, «Los portales», otro poema de capital importancia para comprender en toda su prodigiosa riqueza los aportes de su autor a nuestra sensibilidad y los elementos esenciales de su poética, con «La joven en el teatro», «Vista de una granja al crepúsculo» o «Tú pasaste, tan joven», de su libro de 1977 , o con «En esta extraña calle» o «La página en blanco», de Inventario de asombros. Veamos estas muestras:

Entre la tarde caldeados, desiertos fijamente, a solas esparcían su ociosa figuración de la penumbra los portales profundos, que nunca fueron el umbral venturoso de la siesta, la que rocía con dedos suaves los sonidos y ahonda las estancias, sino que arden hacia dentro como los ojos blancos de los ángeles en sus nichos de piedra que la lluvia rural va desgastando.

Me da terror este papel en blanco $\left(\ll\right.$ Los portales») ${ }^{14}$. tendido frente a mí como el vacío por el que iré bajando línea a línea descolgándome a pulso pozo adentro sin saber dónde voy ni cómo subo trepando atrás palabra tras palabra que apenas sé qué son sino son sólo fragmentos de mí mismo mal atados para bajar a tientas por la sima que es el papel en blanco de aquí afuera poco a poco tornándose otra cosa mientras más crece la presencia oscura de estas líneas si frágiles tan mías que robándole el ser en mí lo vuelven y la transformación en acabándose no es ya el papel papel ni yo el que he sido.

$$
\text { («La página en blanco») }{ }^{15} \text {. }
$$

\footnotetext{
${ }^{14}$ En la Calzada de Jesús del Monte, p. 44.

${ }^{15}$ Inventario de asombros (La Habana: Editorial Letras Cubanas, 1982), p. 5.
} 
Parece como si se hubiese ido depurando el conflicto central -la batalla del poeta contra la muerte - de toda la ornamentación que tan armoniosamente se fundía con la sucesiva enumeración del entorno que hallamos En la Calzada de Jesús del Monte. El estilo pausado, señorial, de alabanza, ha cedido su lugar a un verso mucho más concentrado y que requiere de recursos de expresión de más transparentes vestimentas, como las que se hacen patentes en «Donde nunca jamás se lo imaginan», homenaje a Ernesto «Che» Guevara, un tema inusual en sus libros. Aquella sobreabundancia de imágenes que tanto nos deleitan una y otra vez ha dado lugar a una imagen obsesiva: la presencia de la muerte, una constante desde siempre en toda esta obra, pero más evidente y de más fuerza en los últimos años. Y de tal modo es ésa una constante desde 1942, que constituye el hilo conductor de la creación literaria de Diego y va integrando una a una sus páginas. De los rasgos peculiares de esta obra, aquellos que nos permiten definirla como una extraordinaria lección artística y leerla con el placer que el tiempo no ha sido capaz de extinguir, tenemos que referirnos de nuevo al develamiento de las relaciones ocultas de lo cotidiano en el inagotable universo de objetos, momentos, sitios de la soledad o de la convivencia. Estamos ante una enorme sabiduría acumulada desde muy temprano y transmutada en la percepción de la luz y la penumbra, colores y sonidos, memorias que cobran vida ante nuestros ojos y nos llegan como si fuesen vivencias del pasado propio, temores, alegrías y esperanzas que son de todos y que sólo los poetas logran revivirlas en sus lectores en toda la plenitud de su multiplicidad.

La influencia que ha ejercido la poesía de Eliseo Diego en los poetas cubanos surgidos después de 1959 tiene una gran importancia como testimonio de su significación dentro del panorama lírico nacional en este siglo. Junto a otros nombres (Tallet, Guillén, Fernández Retamar, Jamís, Escardó, Vallejo, Neruda, Borges), Eliseo Diego ha dejado su impronta por el tratamiento del tema de la infancia, la presencia constante del mundo cotidiano, la objetivación de la realidad, cierto tono coloquial, la ausencia de un lirismo intimista, la función creadora de la memoria afectiva, la sencillez sintáctica y lexical, elementos todos manejados con una poderosa eficacia que lo convierte en uno de los creadores cubanos con mayor carga de futuridad. La lección trascendente de Eliseo Diego está en habernos traído la posibilidad de una identificación más profunda y enriquecedora con el paisaje inmediato, con las cosas que conforman el sitio del hombre, experiencia que en su obra no se detiene en descripciones más o menos felices ni en vacías exaltaciones, sino que penetra hasta el encuentro de las oscuras y secretas asociaciones de la realidad, en su afán de que alcancemos el triunfo definitivo contra la Nada y el Vacío. 